\title{
Range extension of Thomasomys princeps (Thomas, 1895) (Rodentia, Sigmodontinae) and first record in Venezuela
}

\author{
Víctor Pacheco ${ }^{1,2}$ \\ 1 Departamento de Mastozoología, Museo de Historia Natural, Universidad Nacional Mayor de San Marcos, Lima, Peru •vpachecot@unmsm. \\ edu.pe (1) https://orcid.org/0000-0002-1005-135X \\ 2 Instituto de Ciencias Biológicas “Antonio Raimondi”, Facultad de Ciencias Biológicas, Universidad Nacional Mayor de San Marcos, Lima, \\ Peru
}

\begin{abstract}
Thomasomys princeps (Thomas, 1895) is a large, sigmodontine rat and a member of the "aureus" group of the highly diverse genus Thomasomys. This species is only known from the Cordillera Oriental, Colombia; however, based on a recent examination of specimens of Thomasomys from Venezuela, I report the first record of T. princeps from Venezuela, in the Páramo del Tamá near the Colombian border. This record extends the distributional range of the species by $360 \mathrm{~km}$ northeast, representing the northernmost record of the species and of the "aureus" group.
\end{abstract}

\section{Keywords}

"Thomasomys aureus group", Colombia, Cordillera Oriental, Ecuador, Páramo del Tamá, Principal Oldfield Mouse, Táchira

Academic editor: Marcus Brandão | Received 13 January 2021 | Accepted 23 February 2021 | Published 5 March 2021

Citation: Pacheco V (2021) Range extension of Thomasomys princeps (Thomas, 1895) (Rodentia, Sigmodontinae) and first record in Venezuela. Check List 17 (2): 385-393. https://doi.org/10.15560/17.2.385

\section{Introduction}

Thomasomys Coues, 1884 is a sigmodontine rodent and a member of the tribe Thomasomyini (Pacheco et al. 2015). The genus is endemic to South America in tropical and subtropical habitats along the Andes, where it is distributed from the Cordillera Santa Marta in Colombia and northern Venezuela to central Bolivia, and where it lives from about $1200 \mathrm{~m}$ to above $4500 \mathrm{~m}$ (Pacheco 2015). Currently, 45 species are recognized in the genus (Pacheco 2015; Brito et al. 2019), and based on phylogenetic analysis of morphological characters, they are contained in seven intrageneric groups (Pacheco 2003, 2015): "aureus", "baeops", “cinereus", "gracilis", "incanus", "macrotis", and "notatus". The Principal Oldfield Mouse, Thomasomys princeps (Thomas 1895), is a large species (total length of head and body 173-198 mm) with a long tail (113-131\% of total length of head and body) and relatively long hindfeet $(36-39 \mathrm{~mm})$. It is a member of the “aureus" group, along with Thomasomys apeco Leo L. \& Gardner, 1993, Thomasomys auricularis Anthony, 1923, Thomasomys pyrrhonotus Thomas, 1886, Thomasomys praetor (Thomas, 1900), Thomasomys nicefori Thomas, 1921, Thomasomys aureus (Tomes, 1860), Thomasomys popayanus J. A. Allen, 1912, and Thomasomys rosalinda Thomas \& St. Leger, 1926 (sensu Pacheco 2015). Thomasomys princeps was described based on a specimen collected from the Bogotá Region, Cundinamarca Department, Colombia, and it is currently known from a few localities along the Cordillera Oriental of Colombia, from 2650 to $3182 \mathrm{~m}$ in montane forests (Pacheco 2015; Calderón-Capote et al. 2016). Outside Colombia, $T$. 
princeps has been reported from Sangay National Park in Morona Santiago Province, Ecuador (Lee et al. 2015); however, an adequate description of external characteristics and morphological details of the skull and teeth were not provided.

Following the description of $T$. princeps by Thomas (1895), Thomas (1900) and Ellerman (1941) recognized it as a valid species, but Cabrera (1961) relegated it to a subspecies of T. aureus without justification, an opinion that was followed by Musser and Carleton (2005) and Voss (2003). More recently, Pacheco (2003, 2015) differentiated T. princeps from T. aureus and other congeneric species using a unique combination of external and craniodental attributes. Calderón-Capote et al. (2016) found that $T$. princeps exhibited a distinct bacular morphology and also supported its status as a valid species.

Pacheco (2015) reported that four species of Thomasomys, T. aureus (Tomes, 1860), T. emeritus Thomas, 1916, T. hylophilus Osgood, 1912, and T. vestitus (Thomas, 1898) occur in Venezuela. While Pacheco's (2015) study indicated that the Venezuelan specimen of $T$. aureus from the Táchira Andes could be distinguished in external and cranial characteristics from other populations of T. aureus, this specimen was not compared to $T$. princeps. Here, based on a direct examination of the specimen of $T$. aureus from Táchira, and side-by-side comparisons with topotypes of $T$. princeps, I have reidentified the specimen and present the first record of $T$. princeps for Venezuela, which extends the known distribution of this species northeast of Colombia.

\section{Methods}

As part of a revision of the genus Thomasomys, I visited the mammal collections of the American Museum of Natural History, New York (AMNH); the National Museum of Natural History, Smithsonian Institution, Washington D.C. (USNM); the Field Museum of Natural History, Chicago (FMNH); the Natural History Museum (NHM), London (formerly the British Museum of Natural History, London; BMNH); and the Instituto de Ciencias Naturales, Universidad Nacional de Colombia, Bogotá (ICN). I took external measurements and weight from specimen tags. The head and body length (HBL) was estimated by subtracting the tail length (TL) from the total length. External measurements are reported to the nearest millimeter (mm), and weights to the nearest gram (g). Cranial and mandibular variables were measured to the nearest $0.1 \mathrm{~mm}$ using dial calipers mainly following Luna and Pacheco (2002): greatest length of skull (GSL), condyloincisive length (CIL), condylomolar length (CML), length of orbital fossa (LOF), length of nasals (LN), diastema length (LD), length of incisive foramina (LIF), length of maxillary toothrow (LM), breadth of incisive foramina (BIF), breadth of rostrum (BR), breadth of palatal bridge (BPB), breadth of first upper molar (BM1), breadth of nasals (BN), least interorbital breadth (LIB), zygomatic breadth (ZB), braincase breadth (BB), breadth of zygomatic plate (BZP), depth of incisor (DI), and height of braincase (HBC). A total of 15 specimens of T. princeps were identified and measured. Age classification followed Carleton and Musser (1989) who presented four age classes: juvenile, young adult, adult, and old adult. Taxonomic identification followed Pacheco (2015).

\section{Results}

After a taxonomic revision of Thomasomys specimens from the northern Andes, I found one record of T. princeps for Venezuela which was previously identified as $T$. aureus (Pacheco 2015). This record constitutes the first of this species from Venezuela (Fig. 1).

New record. VENEZUELA - Department of Táchira, Buena Vista, 41 km SW San Cristobal, near Páramo del Tamá; $07^{\circ} 30^{\prime} \mathrm{N}, 072^{\circ} 24^{\prime} \mathrm{W}$; 2400 m a.s.1.; 8 March 1968; SVP leg. 21873; 1 juvenile 9 , USNM 442321.

The vegetation type at the site where the Táchira specimen was collected corresponds to Bosques Ombrófilos montanos siempreverdes, bosques nublados andinos of the Subregión D2 (Cordillera de los Andes), Región D (Montañas) (sensu Huber and Alarcón 1988) or bosques andinos (sensu Huber and Oliveira-Miranda 2010).

Other material examined. COLOMBIA - Cundina-

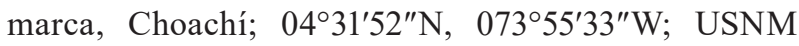
251958 • Cundinamarca, Bogotá region; BM 95.8.1.37holotype, USNM 251957 - Cundinamarca, Laguna Vergon; $04^{\circ} 32^{\prime} \mathrm{N}, 074^{\circ} 04^{\prime} \mathrm{W}$; USNM 251976 - Cundinamarca, Bogotá, Páramo del Verjon; $04^{\circ} 34^{\prime} \mathrm{N}, 074^{\circ} 05^{\prime} \mathrm{W}$; AMNH 62769-62770 • Cundinamarca, Bogotá, San Cristobal; $04^{\circ} 34^{\prime} \mathrm{N}, 074^{\circ} 05^{\prime} \mathrm{W}$; FMNH $71306-71307$ • Cundinamarca, Bogotá, San Francisco; 0443'44"N, $073^{\circ}$ 50'36"W; FMNH 71305 • Cundinamarca, Guasca, Río Balcones; $04^{\circ} 40^{\prime} \mathrm{N}, 073^{\circ} 33^{\prime} \mathrm{W}$; FMNH 71300-71304 • Cundinamarca, Municipio Junín, Reserva Biológica Car-

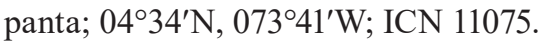

Identification. Thomasomys princeps is a large species (HBL 173-198 mm) with a long tail (113-131\% of HBL) and relatively long hindfeet $(36-39 \mathrm{~mm}$ ), characterized by a unique combination of external and craniodental characters: dorsal pelage long, thick, and not very fluffy, rich orange-rufous, with a faint, dark band along the midline, richer along the sides; ventral pelage clear orange-buff, not counter-shaded; hairs long, about $15 \mathrm{~mm}$ in length, mystacial vibrissae long, extending posteriorly to pinnae when bent; genal 1 vibrissae present. The hindfeet are moderately broad with a dark-brown patch on the metatarsals, silvery whitish on the sides and digits. The tail is long, monocolored, dark brown, covered with short hairs (13 rings per $\mathrm{cm}$ ), and without a terminal pencil. The hallux is long, extending to the interphalangeal joint of digit II; digit V of pes is very long, claw extending to the base of the claw of digit IV; thenar and hypothenar swollen and overlap; digits whitish and ungual tufts long and silvery; protuberance anus is prominent. The skull is large 


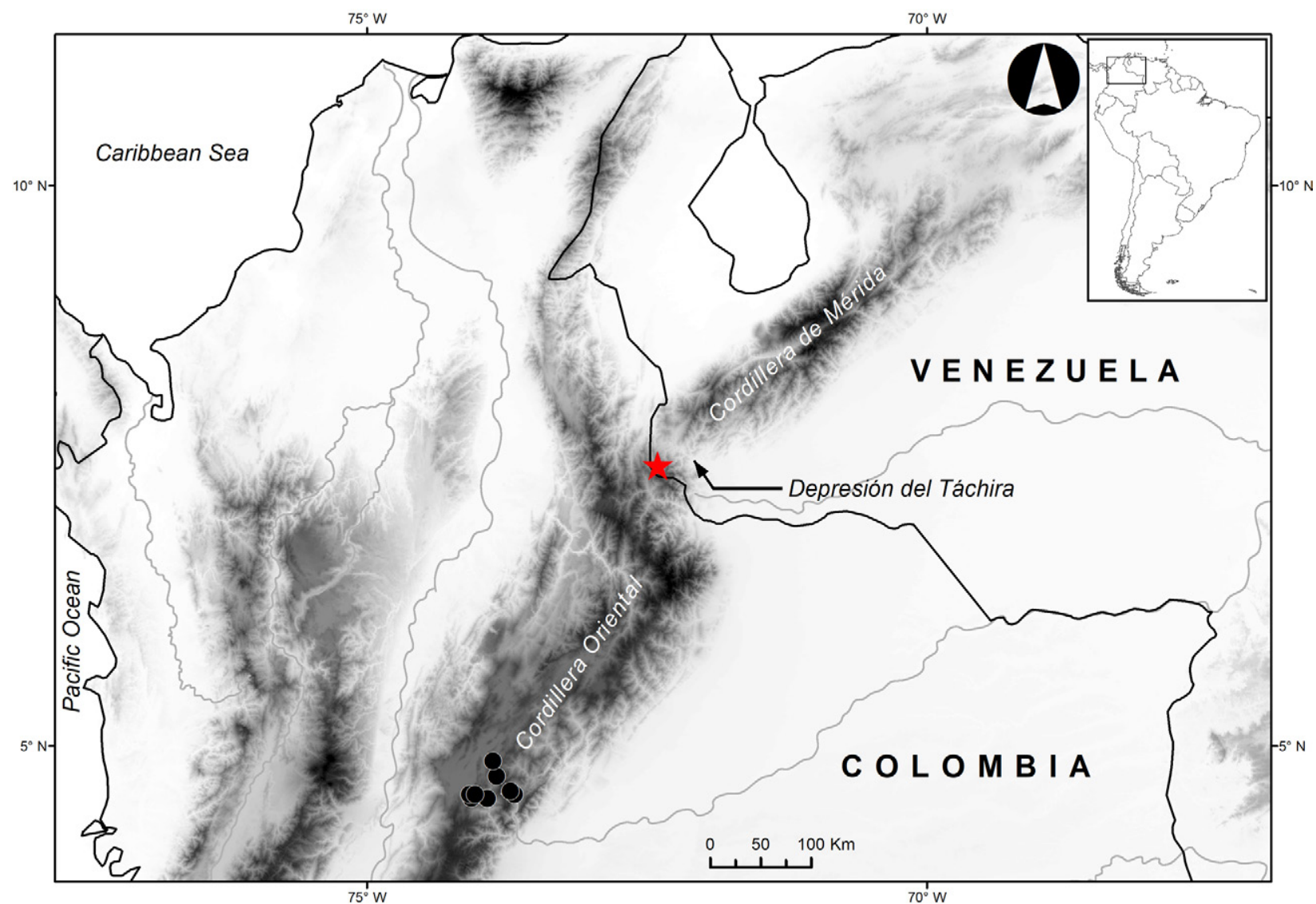

Figure 1. Distribution range of Thomasomys princeps following Pacheco (2015). Previous records of T. princeps from the Bogotá region are represented by black circles and the new record (USNM 442321) from Venezuela, Páramo de Tamá, by a red star.

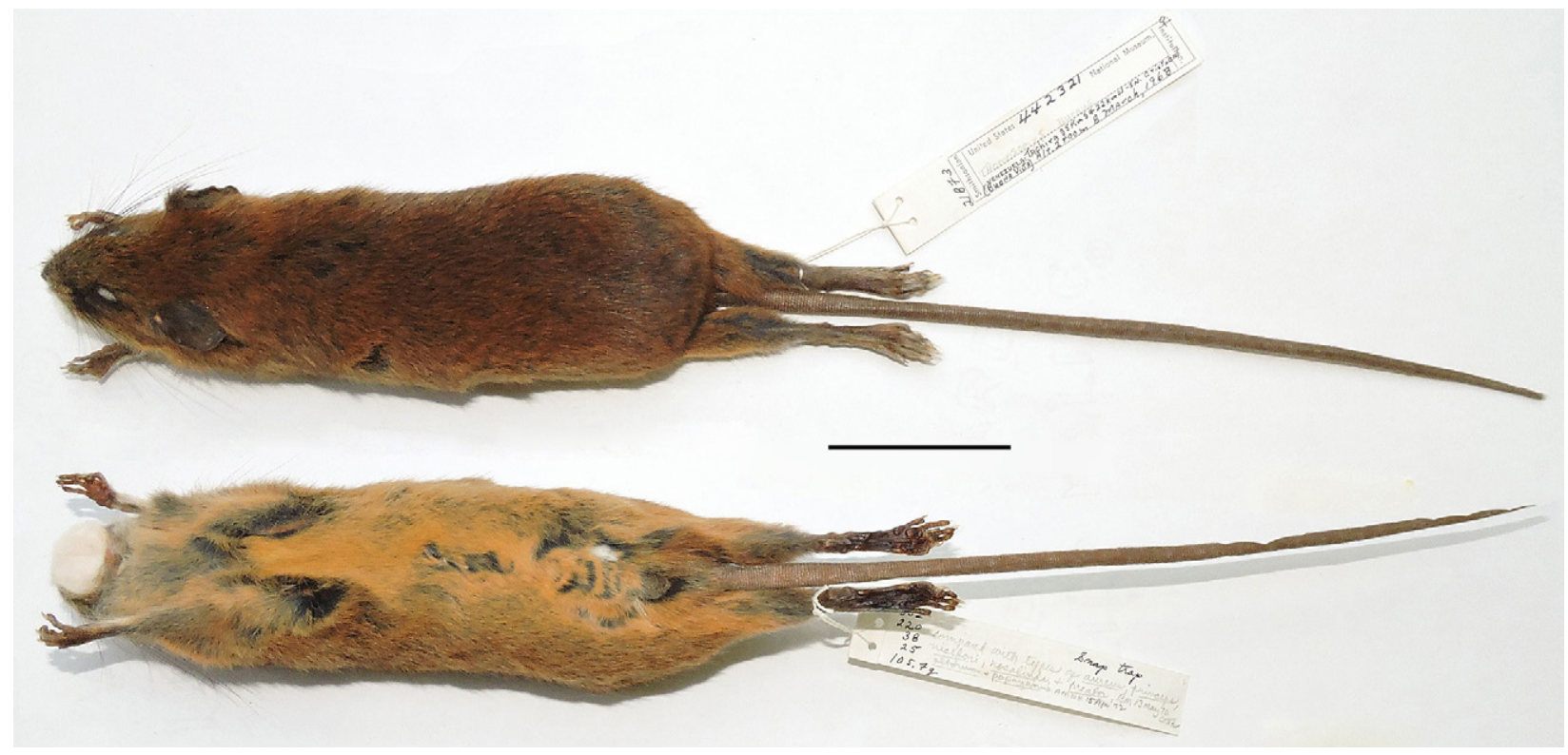

Figure 2. Dorsal and ventral views of the skin of the specimen Thomasomys princeps (USNM 442321) from Venezuela. Scale bar $=50 \mathrm{~mm}$.

and robust (CIL 36.7-39.4 $\mathrm{mm}$ ) and rostrum relatively short and broad; braincase oblong, moderately broad, and not inflated; zygomatic plate is broad and vertical; the anterior border of the premaxillae do not project much beyond the upper incisors; premaxillomaxillaryfrontal intersection anterior to zygomatic notches; nasals long with a narrow posterior tip that extends beyond premaxillae and usually beyond the lacrimals; incisive foramina large and broad penetrating slightly between M1 anterocones; maxillary septum approaching half the length of incisive foramen; interorbital region narrow and slightly convergent anteriorly, with square margins (not beaded); postorbital ridge distinct; anterior margin of M1 placed anterior to the posterior border of the zygomatic plate; M1 anteromedian flexus shallow, anteroflexus indistinct; the mesopterygoid fossa is broad and 
somewhat parallel-sided, without distinct process; posterior opening of the alisphenoid canal large. Capsular process not developed but strongly swollen producing a distinct shelf. Protoflexus M2 indistinct; and ectolophid m1 present (see Pacheco 2015: 672-673 for a detailed description).

The specimen (USNM 442321) agrees with the description of $T$. princeps and has the main diagnostic characteristics of the species (Figs. 2, 3), including the dorsal and ventral pelage coloration, dark metatarsals, the long posterior extension of the nasal, the premaxillo-maxillary-frontal intersection anterior to zygomatic notches; the broad and large incisive foramina that extend between M1s, the anterior position of M1 in relation to the posterior margin of the zygomatic plate, the mesopterygoid fossa broad without distinct process; the short anterior margin of the premaxillae, the capsular process swollen, and the ectolophid on $\mathrm{ml}$ present. This juvenile specimen has measurements that fall within the known range of variation of other examined specimens of $T$. princeps of similar age (Table 1). Compared to T. aureus, $T$. princeps has a larger HBL, smaller ratio HFL/HBL, longer nasals, and broader zygomatic plates (Table 1).

Although T. princeps is similar to T. aureus s.s. (Ecua-

Table 1. External and skull measurements (in $\mathrm{mm}$ ) of Thomasomys princeps (USNM 442321, juvenile) from Venezuela compared to Colombian specimens of T. princeps (juvenile) and Ecuadorian specimens of T. aureus (juvenile). Adult specimens of T. princeps from Colombia and T. aureus from Ecuador are also included for comparisons. Information regarding the vouchers is in the Appendix.

\begin{tabular}{|c|c|c|c|c|c|}
\hline & $\begin{array}{c}\text { T. princeps } \\
\text { Venezuela }\end{array}$ & $\begin{array}{c}\text { T. princeps } \\
\text { Colombia }\end{array}$ & $\begin{array}{c}\text { T. aureus } \\
\text { Ecuador }\end{array}$ & $\begin{array}{c}\text { T. aureus } \\
\text { Ecuador }\end{array}$ & $\begin{array}{c}\text { T. princeps } \\
\text { Colombia }\end{array}$ \\
\hline Age class & Juvenile & Juvenile & Juvenile & Adult & Adult \\
\hline TotalL & 382 & $\begin{array}{c}374.5 \pm 14.8(2) \\
364-385\end{array}$ & $\begin{array}{c}344.5 \pm 7.8(2) \\
339-350\end{array}$ & $\begin{array}{c}391.5 \pm 22(4) \\
360-408\end{array}$ & $\begin{array}{c}412.3 \pm 23.3(6) \\
369-433\end{array}$ \\
\hline Taill & 220 & $\begin{array}{c}206.5 \pm 0.7(2) \\
206-207\end{array}$ & $\begin{array}{c}204 \pm 12.7(2) \\
195-213\end{array}$ & $\begin{array}{c}220 \pm 14.1(4) \\
200-233\end{array}$ & $\begin{array}{c}227.7 \pm 16.4(6) \\
196-242\end{array}$ \\
\hline$H B L$ & 162 & $\begin{array}{c}168 \pm 14.1(2) \\
158-178\end{array}$ & $\begin{array}{c}140.5 \pm 4.9(2) \\
137-144\end{array}$ & $\begin{array}{c}171.5 \pm 8.5(4) \\
160-180\end{array}$ & $\begin{array}{c}184.7 \pm 8.4(6) \\
173-198\end{array}$ \\
\hline TailL/HBL & 1.4 & $\begin{array}{l}1.25(2) \\
1.2-1.3\end{array}$ & $\begin{array}{c}1.5(2) \\
1.4-1.6\end{array}$ & $\begin{array}{c}1.3(4) \\
1.3-1.3\end{array}$ & $\begin{array}{c}1.2(6) \\
1.1-1.3\end{array}$ \\
\hline HFL & 38 & $\begin{array}{c}38 \pm 1.4(2) \\
37-39\end{array}$ & $\begin{array}{c}37.9 \pm 1.3(7) \\
35.5-40\end{array}$ & $\begin{array}{c}37.9 \pm 1.8(15) \\
35-41\end{array}$ & $\begin{array}{c}37.8 \pm 1.1(6) \\
36.2-39\end{array}$ \\
\hline HFL/HBL & 23.5 & $\begin{array}{c}22.7(2) \\
21.9-23.4\end{array}$ & $\begin{array}{c}27.4(2) \\
25.7-29.2\end{array}$ & $\begin{array}{l}21.9(4) \\
20-25\end{array}$ & $\begin{array}{l}20.5(6) \\
18.9-22\end{array}$ \\
\hline EAR & 25 & 24 & $\begin{array}{c}23.5 \pm 0.7(2) \\
23-24\end{array}$ & - & $\begin{array}{c}24.2 \pm 1.1(5) \\
23-26\end{array}$ \\
\hline GSL & 38.7 & - & $\begin{array}{c}37.3 \pm 0.6(2) \\
36.9-37.7\end{array}$ & $\begin{array}{c}40.1 \pm 1(11) \\
38.1-41.7\end{array}$ & $\begin{array}{c}41.4 \pm 0.8(5) \\
40.6-42.5\end{array}$ \\
\hline CIL & 35.1 & 33.7 & $\begin{array}{c}33.8 \pm 0.9(2) \\
33.1-34.4\end{array}$ & $\begin{array}{c}36.9 \pm 1.1(12) \\
35.4-39.5\end{array}$ & $\begin{array}{c}38.1 \pm 0.9(6) \\
36.7-39.4\end{array}$ \\
\hline CML & 22.7 & $\begin{array}{c}22.7 \pm 0.3(2) \\
22.5-22.8\end{array}$ & $\begin{array}{c}22.6 \pm 0.3(2) \\
22.4-22.7\end{array}$ & $\begin{array}{c}24.1 \pm 0.8(13) \\
22.6-25.9\end{array}$ & $\begin{array}{c}24.7 \pm 0.8(6) \\
23.5-25.7\end{array}$ \\
\hline LOF & 12.3 & $\begin{array}{c}12.6 \pm 0.2(3) \\
12.3-12.8\end{array}$ & $\begin{array}{c}12.1 \pm 0.3(3) \\
11.7-12.3\end{array}$ & $\begin{array}{c}13.0 \pm 0.5(18) \\
12.3-14.1\end{array}$ & $\begin{array}{c}13.9 \pm 0.2(7) \\
13.6-14.3\end{array}$ \\
\hline LN & 15 & 14.7 & $\begin{array}{c}14.4 \pm 0.4(3) \\
14.1-14.8\end{array}$ & $\begin{array}{c}14.9 \pm 0.6(14) \\
13.9-15.9\end{array}$ & $\begin{array}{c}16.1 \pm 0.8(7) \\
15.5-17.7\end{array}$ \\
\hline LD & 10.2 & $\begin{array}{c}9.9 \pm 0.6(2) \\
9.4-10.3\end{array}$ & $\begin{array}{c}9.6 \pm 0.7(3) \\
8.9-10.2\end{array}$ & $\begin{array}{c}10.7 \pm 0.4(15) \\
10.2-11.4\end{array}$ & $\begin{array}{c}11.1 \pm 0.4(8) \\
10.7-12\end{array}$ \\
\hline LIF & 8 & $\begin{array}{c}7.7 \pm 0.6(3) \\
7.1-8.2\end{array}$ & $\begin{array}{c}7.8 \pm 0.3(3) \\
7.6-8.2\end{array}$ & $\begin{array}{c}8.6 \pm 0.3(15) \\
8-9.1\end{array}$ & $\begin{array}{c}8.6 \pm 0.2(8) \\
8.5-9.1\end{array}$ \\
\hline LM & 6.9 & $\begin{array}{c}7.2 \pm 0.2(3) \\
7-7.4\end{array}$ & $\begin{array}{c}7.2 \pm 0.3(7) \\
6.8-7.6\end{array}$ & $\begin{array}{c}7.3 \pm 0.2(18) \\
6.8-7.8\end{array}$ & $\begin{array}{c}7.4 \pm 0.2(8) \\
7.2-7.7\end{array}$ \\
\hline BIF & 3 & $\begin{array}{c}2.7 \pm 0.2(3) \\
2.5-2.9\end{array}$ & $\begin{array}{c}3 \pm 0.2(3) \\
2.8-3.3\end{array}$ & $\begin{array}{c}3.1 \pm 0.2(16) \\
2.9-3.5\end{array}$ & $\begin{array}{c}3.0 \pm 0.3(8) \\
2.6-3.4\end{array}$ \\
\hline$B R$ & 6.3 & $\begin{array}{c}6 \pm 0.3(3) \\
5.7-6.2\end{array}$ & $\begin{array}{c}5.9 \pm 0.4(3) \\
5.6-6.4\end{array}$ & $\begin{array}{c}6.6 \pm 0.2(17) \\
6-7\end{array}$ & $\begin{array}{c}6.6 \pm 0.3(8) \\
6.2-7\end{array}$ \\
\hline BPB & 3.1 & $\begin{array}{c}3.1 \pm 0.3(3) \\
2.7-3.4\end{array}$ & $\begin{array}{c}2.9 \pm 0.1(3) \\
2.8-3\end{array}$ & $\begin{array}{c}3.5 \pm 0.2(18) \\
3.2-3.9\end{array}$ & $\begin{array}{c}3.6 \pm 0.4(8) \\
3.1-4.4\end{array}$ \\
\hline BM1 & 1.9 & $\begin{array}{c}2.1 \pm 0(3) \\
2.1-2.1\end{array}$ & $\begin{array}{c}2.1 \pm 0.1(6) \\
2-2.2\end{array}$ & $\begin{array}{c}2.2 \pm 0.1(18) \\
2.1-2.3\end{array}$ & $\begin{array}{c}2.2 \pm 0.1(8) \\
2.1-2.4\end{array}$ \\
\hline BN & 3.7 & 4.3 & $\begin{array}{c}3.9 \pm 0.3(3) \\
3.6-4.2\end{array}$ & $\begin{array}{c}4.4 \pm 0.2(14) \\
4-4.7\end{array}$ & $\begin{array}{c}4.5 \pm 0.3(8) \\
3.9-4.9\end{array}$ \\
\hline LIB & 5.2 & $\begin{array}{c}5.3 \pm 0.1(3) \\
5.2-5.4\end{array}$ & $\begin{array}{c}5 \pm 0.1(3) \\
5-5.1\end{array}$ & $\begin{array}{c}5.2 \pm 0.2(17) \\
4.9-5.6\end{array}$ & $\begin{array}{c}5.3 \pm 0.2(8) \\
5-5.6\end{array}$ \\
\hline$Z B$ & 19 & $\begin{array}{c}19.2 \pm 0.3(2) \\
19-19.4\end{array}$ & $\begin{array}{c}19 \pm 0.5(3) \\
18.4-19.3\end{array}$ & $\begin{array}{c}20.7 \pm 0.4(13) \\
20-21.2\end{array}$ & $\begin{array}{c}21.1 \pm 0.3(7) \\
20.7-21.5\end{array}$ \\
\hline BB & 16.3 & $\begin{array}{c}16.7 \pm 0.6(2) \\
16.3-17.1\end{array}$ & $\begin{array}{c}16 \pm 0.7(3) \\
15.3-16.7\end{array}$ & $\begin{array}{c}16.6 \pm 0.6(14) \\
15.9-17.8\end{array}$ & $\begin{array}{c}17.4 \pm 0.9(8) \\
16.2-18.8\end{array}$ \\
\hline BZP & 3.7 & $\begin{array}{c}3.6 \pm 0.1(3) \\
3.5-3.6\end{array}$ & $\begin{array}{c}3.2 \pm 0.2(7) \\
3-3.5\end{array}$ & $\begin{array}{c}3.3 \pm 0.1(18) \\
3.2-3.6\end{array}$ & $\begin{array}{c}3.7 \pm 0.3(8) \\
3.4-4.4\end{array}$ \\
\hline DI & 1.9 & $\begin{array}{c}1.9 \pm 0.2(2) \\
1.7-2\end{array}$ & $\begin{array}{c}1.7 \pm 0.2(7) \\
1.6-2\end{array}$ & $\begin{array}{c}2.1 \pm 0.1(15) \\
1.9-2.2\end{array}$ & $\begin{array}{c}2.2 \pm 0.1(8) \\
2.1-2.3\end{array}$ \\
\hline$H B C$ & 11.4 & $\begin{array}{c}11.5 \pm 0(2) \\
11.5-11.5\end{array}$ & $\begin{array}{c}10.8 \pm 0.2(3) \\
10.6-11.1\end{array}$ & $\begin{array}{c}11.2 \pm 0.4(10) \\
10.7-11.9\end{array}$ & $\begin{array}{c}12 \pm 0.6(6) \\
11.1-12.6\end{array}$ \\
\hline
\end{tabular}




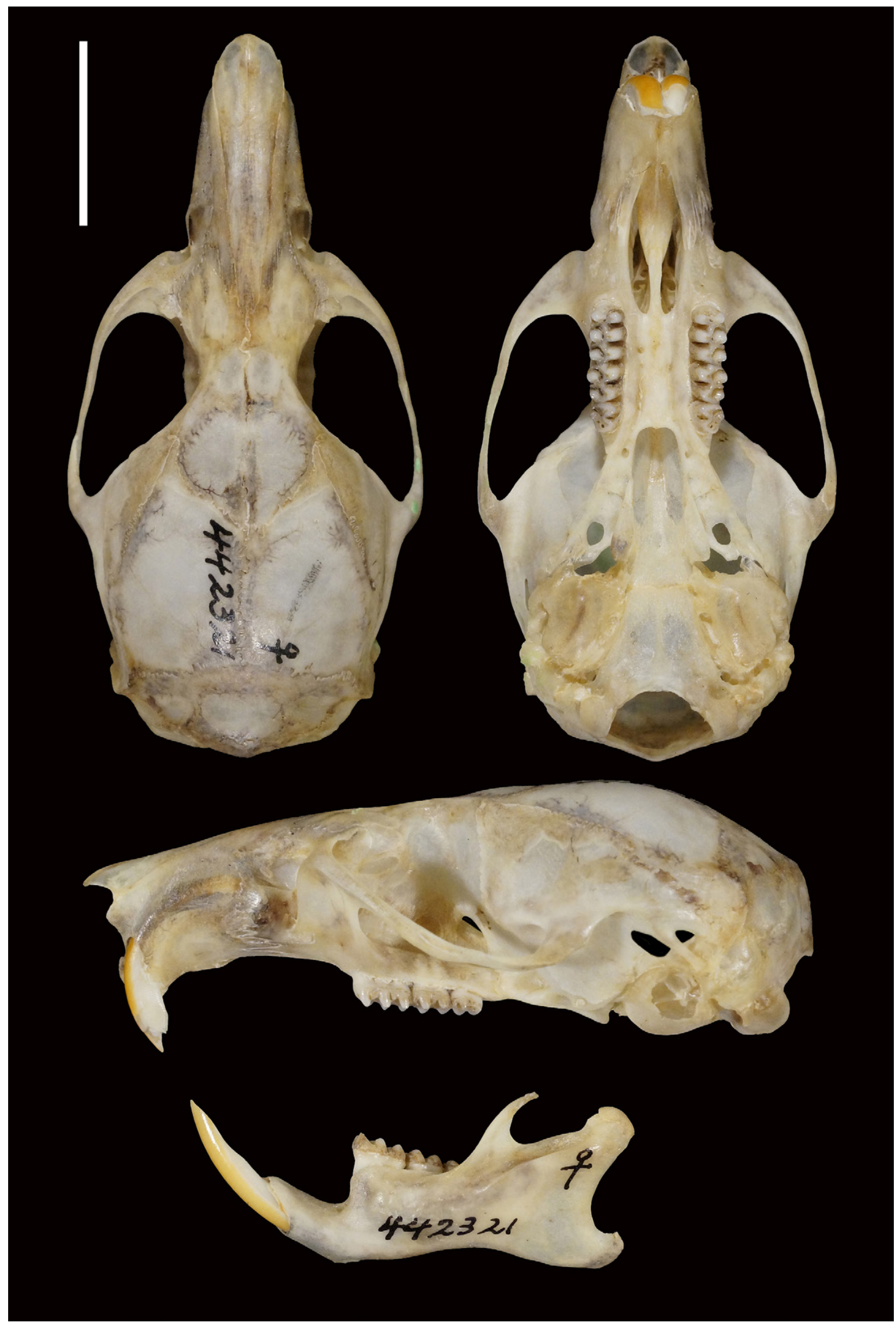

Figure 3. Dorsal, ventral, and lateral views of the skull, and lateral view of the mandible of Thomasomys princeps (USNM 442321, juvenile) from Venezuela. Scale bar $=10 \mathrm{~mm}$. 


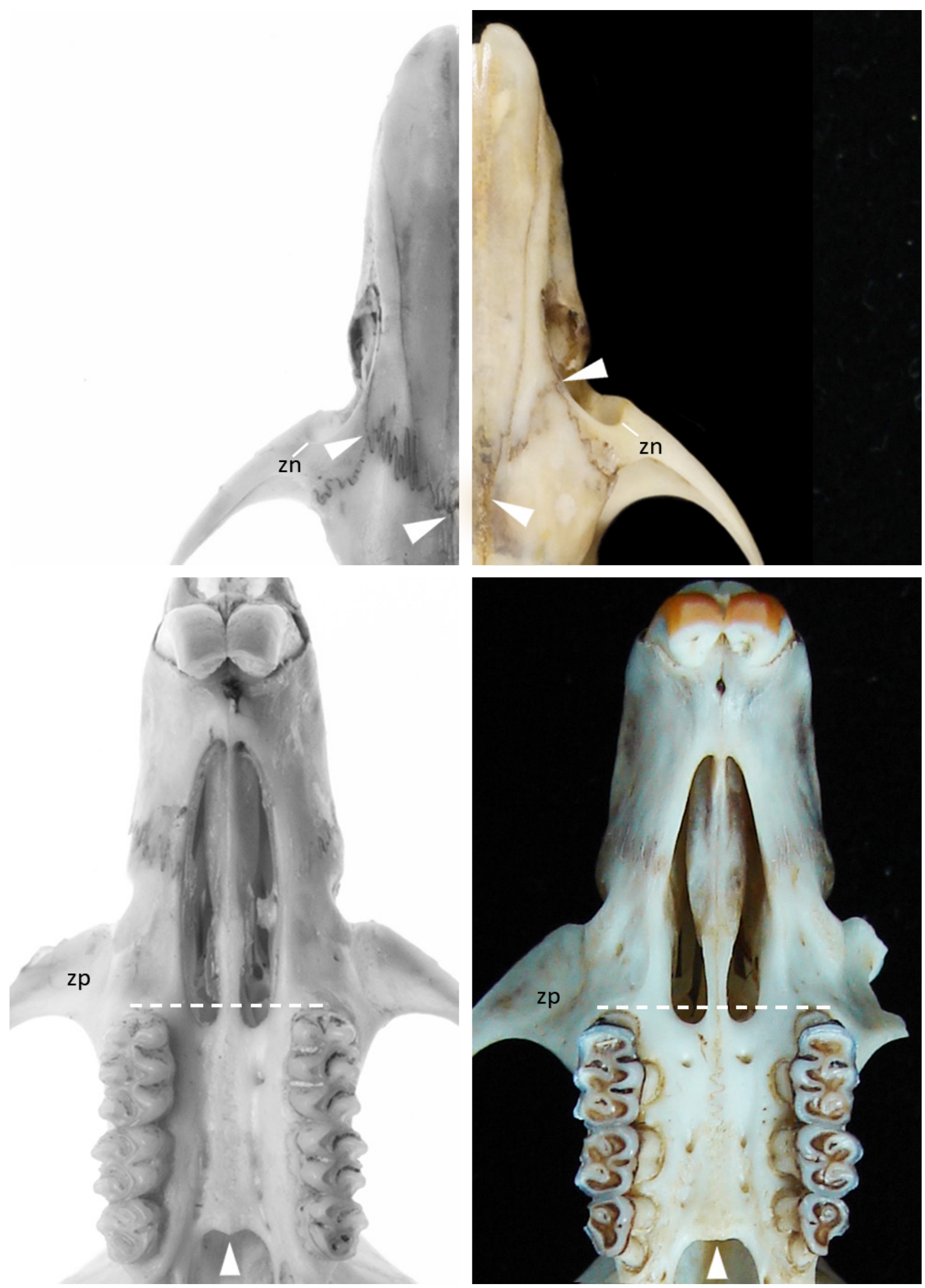

Figure 4. Comparative views of selected characteristics of Thomasomys princeps on the right side (USNM 251957, up; ICN 11075, below) and T. aureus on the left side (AMNH 46590). Abbreviations: $\mathbf{z n}=$ zygomatic notch, $\mathbf{z p}=$ zygomatic plate. 
dorean populations), it can be differentiated by the following characters (Fig. 4): the short anterior border of the premaxillae of $T$. princeps does not project much beyond upper incisors; the premaxillary-maxillary-frontal intersection lies distinctly anterior of the zygomatic notch rather than level to it; nasals are longer and usually extend posteriorly beyond the lacrimals; the incisive foramina are broad and oval-shaped rather than narrow, the posterior opening of the alisphenoid canal is comparatively larger; M1 is placed anterior to the posterior border of zygomatic plate rather than level or posterior to them; palatal bone without a posterior process; capsular process are strongly swollen producing a distinct shelf versus absent; M1 anteromedian flexus is shallow and anteroflexus is indistinct versus distinct; protoflexus of M2 is indistinct; and an ectolophid on $\mathrm{m} 1$ is present versus absent (see Voss 2003 and Pacheco 2015 for the description of T. aureus). In the Cordillera Oriental of Colombia and nearby Venezuela, there are no other species of the "aureus" group that could be confused with T. princeps.

\section{Discussion}

This study represents the first report of Thomasomys princeps in Venezuela and extends the current distribution range of the species about $360 \mathrm{~km}$ to the northeast from Guasca, Río Balcones (Cundinamarca, Colombia). This specimen was previously misidentified as $T$. aureus because of the scarce material for comparisons (Pacheco 2015); therefore, the northernmost range for $T$. aureus is now restricted to Colombian specimens, near to Risaralda and Caldas (Pacheco 2015; Calderón-Capote et al. 2016). Nonetheless, a full revision of T. aureus including representatives of the type locality, presumably Pallatanga in Ecuador (Pacheco 2015), is needed to test if Colombian and Ecuadorian specimens of T. aureus are conspecific.

The Táchira specimen was collected at $2400 \mathrm{~m}, 267$ $\mathrm{m}$ lower than previously known for $T$. princeps, and near Páramo del Tamá in montane forests. Regarding the Páramo del Tamá, Woodman (2002) commented that Osgood (1912) had already noted that the term "páramo" was used to designate the entire highland area (rather than the open, high-elevation vegetational formation with which it is more currently associated). López-Arévalo et al. (1993) reported this species, based on a specimen misidentified as T. aureus, from Biological Reserve Carpanta, Municipio Junín, Cundinamarca, Colombia, and provide a detailed characterization of climate and habitat. Their sampling area was between 3000 and $3100 \mathrm{~m}$ and contained montane forests ( $42 \%$ ), páramo and an ecotone (58\%); however, they did not specify in which habitat $T$. princeps was collected. Calderón-Capote et al. (2016) analyzed the bacular morphology of two specimens of $T$. princeps captured in Encenillo forests, Parque Nacional Natural Chingaza. Mountain forests of "Encenillo" are dominated by Weinmannia sp. (Mendoza-C 2007).
The Táchira specimen also confirms $T$. princeps is restricted to the Cordillera Oriental, in a distribution pattern similar to that of T. laniger (Thomas, 1895), T. hylophilus Osgood, 1912, and T. niveipes (Thomas, 1896), as described by Pacheco (2015). Therefore, it is likely the northern range of $T$. princeps is limited by the Táchira depression, a potential biogeographic barrier (e.g., Vuilleumier and Ewert 1978; Cracraft 1985; Quiroga-Carmona and Molinari 2012); but additional sampling in the Cordillera de Mérida is needed to test this hypothesis. Likewise, T. vestitus (Thomas, 1898), T. emeritus Thomas, 1916, and the thomasomyine Aepeomys Thomas, 1898 are restricted to the Cordillera de Mérida (Pacheco 2015) and are currently unknown in the Cordillera Oriental. More recently, Gutiérrez et al. (2015) challenged the role of the Táchira depression as a dispersal barrier for Little Red Brocket, Mazama rufina, suggesting that gene flow between populations of M. rufina in the Cordillera Oriental and Cordillera de Mérida may have occurred until at least the beginning of the current interglacial period and may continue today. The data available for $T$. princeps and other thomasomyines suggest that the biogeographic pattern is different for these rodents, likely due to their small size and limited mobility, and that the Táchira Depression appears to play a significant role in the distribution of these mountain rodents.

Thomasomys princeps was reported in Ecuador, from Morona Santiago, Sangay National Park (Lee et al. 2015). Recently, Brito et al. (2019) found that the sequence of one of those specimens (QCAZ 11939; KR818905.1 in GeneBank) identified as $T$. princeps formed a strong clade with other sequences of T. aureus (MECN 5662, 5666) from Chimborazo, Chambo, Parque Nacional Sangay, Atillo. Brito et al. (2019)'s clade of aureus-princeps could indeed represent T. aureus s.s., T. princeps, or a new taxon, but they made no taxonomic comment. Pending a thorough revision, these specimens (and sequences) from Ecuador are tentatively not recognized here as princeps because the identification was not properly sustained by comparisons with the holotype of $T$. princeps or topotypes from Cundinamarca.

The Principal Oldfield Mouse is still a poorly known rodent, currently classified as Data Deficient by the IUCN (Pacheco and Barriga 2019). Sequence data, karyotype, and many morphological attributes (e.g., skeleton, internal organs) are not yet available, limiting the understanding of its phylogenetic position. This contribution considerably extends the northern range of the species and highlights the need to test its presence in the range between Bogotá region and the Colombian border with Venezuela.

\section{Acknowledgements}

I want to thank Jorge Carrera for preparing the map and Mercedes Molina for helping with the images. Also, I thank Dennisse Ruelas and Silvia Diaz for helping with the table and commenting on the manuscript. Catherine Sahley also provided valuable comments on the 
manuscript and improved the English. Besides, Darrin Lunde provided me access to specimens of Thomasomys deposited at the National Museum of Natural History (USNM). This work was partially supported by the Grupo de Estudio Diversidad de mamíferos y sus parásitos (DIMAPA) del Vicerrectorado de Investigación y Posgrado UNMSM.

\section{References}

Allen JA (1912) Mammals from western Colombia. Bulletin of the American Museum of Natural History 31: 71-95.

Anthony HE (1923) Preliminary report on Ecuadorean mammals (No. 3). American Museum Novitates 55: 1-14.

Brito J, Tinoco N, Curay J, Vargas R, Reyes-Puig C, Romero V, Pardiñas UFJ (2019) Diversidad insospechada en los Andes de Ecuador: filogenia del grupo "cinereus" de Thomasomys y descripción de una nueva especie (Rodentia, Cricetidae). Mastozoología Neotropical 26 (2): 308-330. https://doi.org/10.31687/sarem MN.19.26.2.0.04

Cabrera A (1961) Catálogo de los mamíferos de América del Sur. Revista del Museo Argentino de Ciencias Naturales "Bernardino Rivadavia" (Ciencias Zoológicas) 4(2): xxii + 309-732

Calderón-Capote MC, Jerez A, Sánchez-Palomino P, López-Arévalo HF (2016) Bacular morphology of seven species of high andean rodents from Colombia (Rodentia: Sigmodontinae). Mastozoologia Neotropical 23 (1): 25-37.

Carleton MD, Musser GG (1989) Systematic studies of oryzomine rodents (Muridae, Sigmodontinae): a synopsis of Microryzomys Bulletin of the American Museum of Natural History 191:1-83.

Coues E (1884) Thomasomys, a new subgeneric type of Hesperomys. The American Naturalist 18: 1275-1275.

Cracraft J (1985) Historical biogeography and patterns of differentiation within the South American avifauna: areas of endemism. Ornithological Monograph 36: 49-84. https://doi.org/10.2307/4016 8278

Ellerman JR (1941) The families and genera of living rodents: family Muridae, Volume 2. Trustees of the British Museum (Natural History), London, UK, xii + 690 pp.

Gutiérrez EE, Maldonado JE, Radosavljevic A, Molinari J, Patterson BD, Martínez-C JM, Rutter AR, Hawkins MTR, Garcia FJ, Helgen KM (2015) The taxonomic status of Mazama bricenii and the significance of the Táchira depression for mammalian endemism in the Cordillera de Mérida, Venezuela. PLoS ONE 10 (6): e0129113. https://doi.org/10.1371/journal.pone.0129113

Huber O, Alarcón C (1988). Mapa de Vegetación de Venezuela. Ministerio del Ambiente y los Recursos Naturales Renovables, The Nature Conservancy, Fundación Bioma, Caracas, Venezuela.

Huber O, Oliveira-Miranda MA (2010) Ambientes terrestres. En: Rodríguez JP, Rojas-Suárez F, Giraldo-Hernández D (Eds.) Libro Rojo de los ecosistemas terrestres de Venezuela. Provita, Shell Venezuela, Lenovo, Caracas, Venezuela, 29-89.

Lee TE, Ritchie AR, Vaca-Puente S, Brokaw JM, Camacho MA, Burneo SF (2015) Small mammals of Guandera Biological Reserve, Carchi Province, Ecuador and comparative Andean small mammal ecology. Occasional Papers of the Museum of Texas Tech University 334: 1-17.

Leo M, Gardner AL (1993) A new species of a giant Thomasomys (Mammalia: Muridae: Sigmodontinae) from the Andes of northcentral Peru. Proceedings of the Biological Society of Washington 106(3): 417-428.

López-Arévalo H, Montenegro-Díaz O, Cadena A (1993) Ecología de los pequeños mamíferos de la Reserva Biológica Carpanta, en la Cordillera Oriental colombiana. Studies on neotropical fauna and environment 28: 193-210.

Luna L, Pacheco V (2002) A new species of Thomasomys (Muridae:
Sigmodontinae) from the Andes of southeastern Peru. Journal of Mammalogy 83: 834-842. https://doi.org/10.1644/1545-1542 (2002)083<0834:ansotm $>2.0$. co;2

Mendoza-C H (Compilador) (2007). Caracterización biológica de cuatro áreas del Parque Nacional Natural Chingaza, Cundinamarca, Colombia. Informe interno. Instituto de Investigación de Recursos Biológicos Alexander von Humboldt, Bogotá, Colombia, 187 pp. http://repository.humboldt.org.co/bitstream/handle/20.500. 11761/31351/08-08-25-0108.pdf. Accessed on: 2021-1-1.

Musser GG, Carleton MD (2005) Superfamily Muroidea. In: Wilson DE, Reeder DM (Eds.) Mammal species of the world: a taxonomic and geographic reference. 3rd edition. The Johns Hopkins Press, Baltimore, MD, USA, 894-1531.

Osgood WH (1912) Mammals from western Venezuela and eastern Colombia. Field Museum of Natural History, Zoological Series 10 (5): 33-66. https://doi.org/10.5962/bhl.title.2647

Pacheco V (2003) Phylogenetic analyses of the Thomasomyini (Muroidea: Sigmodontinae) based on morphological data. PhD thesis, The City University New York, NY, USA, xvii + 398pp.

Pacheco V (2015) Genus Thomasomys Coues, 1884. In: Patton JL, Pardiñas UFJ, D’Elia G (Eds.) Mammals of South America. Volume 2: rodents. University of Chicago Press, Chicago, IL, USA, 617-683.

Pacheco V, Barriga C (2019) Thomasomys princeps. The IUCN Red List of Threatened Species 2019: e.T96801288A96801291. https:// doi.org/10.2305/IUCN.UK.2019-1.RLTS.T96801288A96801291. en. Accessed on: 2021-1-13.

Pacheco V, Patton JL, D'Elía G (2015) Tribe Thomasomyini Steadman and Ray, 1982. In: Patton JL, Pardiñas UFL, D’Elía G (Eds.) Mammals of South America. Volume 2: rodents. The University of Chicago Press, Chicago, IL, USA, 571-574.

Quiroga-Carmona M, Molinari J (2012) Description of a new shrew of the genus Cryptotis (Mammalia: Soricomorpha: Soricidae) from the Sierra de Aroa, an isolated mountain range in northwestern Venezuela, with remarks on biogeography and conservation. Zootaxa 3441 (1): 1-20. https://doi.org/10.11646/zootaxa.3441.1.1

Thomas O (1886) Note on Hesperomys pyrrhorhinus, Pr. Max. Annals and Magazine of Natural History (Series 5) 18 (108): 421-423. https://doi.org/10.1080/00222938609459994

Thomas O (1895) On small mammals from Nicaragua and Bogota. Annals and Magazine of Natural History (Series 6) 16 (91): 55-60. https://doi.org/10.1080/00222939508680228

Thomas O (1898) On seven new small mammals from Ecuador and Venezuela. Annals and Magazine of Natural History (Series 7) 1 (6): 451-457. https://doi.org/10.1080/00222939808678001

Thomas O (1900) Description of two new murines from Peru and a new hare from Venezuela. Annals and Magazine of Natural History (Series 7) 5 (28): 354-357. https://doi.org/10.1080/0022293000 8678298

Thomas O (1916) Two new Muridae from South America. Annals and Magazine of Natural History (Series 8$) 18$ (108): 478-480. https:// doi.org/10.1080/00222931609486903

Thomas O (1921) New Cryptotis, Thomasomys, and Oryzomys from Colombia. Annals and Magazine of Natural History (Series 9) 8 (45): 354-357. https://doi.org/10.1080/00222932108632593

Thomas O, Leger JSt (1926) The Godman-Thomas expedition to Peru.- IV. On mammals collected by Mr. R. W. Hendee north of Chachapoyas, Province of Amazonas, north Peru. Annals and Magazine of Natural History (Series 9) 18 (106): 345-349. https:// doi.org/10.1080/00222932608633524

Tomes RF (1860) Notes on a third collection of Mammalia made by Mr. Fraser in the Republic of Ecuador. Proceedings of the Zoological Society of London: 260-268.

Voss RS (2003) A new species of Thomasomys (Rodentia: Muridae) from eastern Ecuador, with remarks on mammalian diversity and biogeography in the Cordillera Oriental. American Museum Novitates: 3421: 1-47

Vuilleumier F, Ewert DN (1978) The distribution of birds in the Ven- 
ezuelan paramos. Bulletin of the American Museum of Natural History 162 (2): 47-90.

Woodman N (2002) A new species of small-eared shrew from Colom- bia and Venezuela (Mammalia: Soricomorpha: Soricidae: Genus Cryptotis). Proceedings of the Biological Society of Washington 115 (2): 249-272.

\section{Appendix}

Table A1. List of specimens of Thomasomys aureus measured for comparisons with T. princeps in Table 1. Age classes follow Carleton and Musser (1989).

\begin{tabular}{lll}
\hline Catalog no. & Locality & Age class \\
\hline AMNH 46653 & Ecuador: Pichincha, Mt. Mojanda (south) San Jose & Adult \\
AMNH 64698 & Ecuador: Pichincha, Mt. Pichincha, San Ignacio & Adult \\
AMNH 36280 & Ecuador: Pichincha, Pichincha & Adult \\
AMNH 46577 & Ecuador: Pichincha, Guapulo & Adult \\
AMNH 46583 & Ecuador: Pichincha, Pichincha, above Quito & Adult \\
AMNH 46585 & Ecuador: Pichincha, Mt. Mojanda (south slope), Peruchu & Adult \\
AMNH 46590 & Ecuador: Pichincha, outside Quito, La Carolina & Adult \\
AMNH 46595 & Ecuador: Pichincha, outside Quito & Adult \\
AMNH 46596 & Ecuador: Pichincha, outside Quito, La Carolina & Adult \\
AMNH 46602 & Ecuador: Pichincha, Guapulo & Adult \\
AMNH 46603 & Ecuador: Pichincha, Zambiza, NE Quito & Adult \\
AMNH 46608 & Ecuador: Pichincha, Machangara River & Adult \\
AMNH 46654 & Ecuador: Pichincha, Mt. Mojanda (south slope) & Adult \\
\hline
\end{tabular}

\begin{tabular}{lll}
\hline Catalog no. & Locality & Age class \\
\hline AMNH 46657 & Ecuador: Pichincha, Mt. Mojanda (south slope), Piganta & Adult \\
AMNH 46660 & Ecuador: Pichincha, outside Quito, Charipuraz & Adult \\
AMNH 46665 & Ecuador: Pichincha, Machangara River & Adult \\
AMNH 64701 & Ecuador: Pichincha, Guapulo & Adult \\
MSB 70707 & Ecuador: Bolivar, Rio Tatahuazo & Adult \\
AMNH 46592 & Ecuador: Pichincha, Quito, Chaupicruz & Juvenile \\
AMNH 46593 & Ecuador: Pichincha, outside Quito & Juvenile \\
AMNH 46594 & Ecuador: Pichincha, Quito, Chaupicruz & Juvenile \\
AMNH 46598 & Ecuador: Pichincha, outside Quito & Juvenile \\
AMNH 46601 & Ecuador: Pichincha, Machangara River & Juvenile \\
UMMZ 127115 & Ecuador: Pichincha, Mt. Pichincha & Juvenile \\
USNM 513588 & Ecuador: Pichincha, Rio Condor Huachana, 3.45 km NE Lloa & Juvenile \\
& & \\
\hline
\end{tabular}

